\title{
A Study on the Organizational Justice and Organizational Citizenship Dimensions and Behaviors
}

\author{
Bülent Güven ${ }^{\mathrm{a}}$, Ali Gürsoy ${ }^{\mathrm{b}}$ \\ a Ministry of Internal Affairs, Ankara, Turkey \\ b Turkish Land Forces, Ankara, Turkey
}

\begin{abstract}
The aim of this study is to carry out an applied research on the relationship and interaction between organizational justice and organizational citizenship behaviors and dimensions in a context of an effective literature study. The application part of the study includes the analyses and testing of the hypotheses which have been formed out of an empirical study on the workers of a textile factory in Osmancik region of the city of Çorum. The study takes advantage of the scales of organizational citizenship and organizational justice. The findings have been scanned through the sources both in Turkey and the whole world and the results have been interpreted in the light of the information gathered.
\end{abstract}

Key Words: Organizational Behavior, Justice, Altruism, Conscience, Courtesy

(C) 2014 Beykent University 


\section{Introduction}

The organizational justice which affects the professional motivation, satisfaction and the behaviors of the employees has gained great importance lately and many researches are being made on this field nowadays. Directly affecting the self-confidence and motivation of the employees, the organizational justice is an important point for an organization to reach its targets and form its strategies.

Based on voluntary principle, the organizational citizenship behavior is an important issue to be analyzed. The organizational citizenship behavior, with its increasing importance today, has paved its way to many disciplines such as organizational behavior, human resources management, marketing, hospital and health services, community psychology, strategic management, international management, economics, business law and military psychology (Köse etc. 2003:2). This is a result of the increase in the number of the studies made especially on the organizational citizenship behavior (Fodchuk, 2007:27).

The main aim of this study is to analyze the scales of effect of the perception of organizational justice on the organizational citizenship behavior and its dimensions and reveal the relationship between the organizational justice and organizational citizenship behavior.

The first part of the study is composed of the literature study; while the second part is composed of sections in which the results of quantitative research on business will be analyzed. In the first part of the contextual framework, the definition, dimensions and the features of the organizational citizenship behavior are discussed.

In the second section of the first part, the theories about the organizational justice will be explained in detail. In the application section of the study, an empirical study on the employees of a factory will show whether there is a relationship between the organizational justice and organizational citizenship behavior and whether the organizational justice affects the organizational citizenship behavior and its dimensions. Moreover, the results from testing the other findings and the hypotheses developed will be discussed and assessed.

\section{Literature Review}

\subsection{Organizational Citizenship Behavior (OCB)}

Studying the duties of the members of an organization that are not included in their job descriptions, in other words, voluntary behaviors, Chester Bernard laid the foundations of the concept of organizational citizenship behavior (Danaeefard etc., 2010: 148). Bateman and Organ (1983) define the organizational citizenship behavior as "good soldier syndrome" while George (1991) defines it as pro-social and then George and Brief define it as a "spontaneous behavior" (Gürbüz, 2006: 50-51). George and Jones (1997: 155) named the concept that has the features of the organizational citizenship behavior as organizational 
voluntarism (or willingness). Goodman and Svyantek (1991) defined the OCB as contextual performance while Finkelstein and Penner (2004) defined it as "social organizational behavior" (Sezgin, 2005:319).

The factor that shaped the organizational citizenship behavior that is defined as "extra-role behavior" by Katz and Kahn (978:76) is the employee performing voluntary deeds without an expectation of an award or punishment except for his responsibilities. In the context of extra-role behavior, the employee performs extra effort without an expectation (Greenberg and Baron 2000:212). Brief and Motowidlo (1986:710) define the organizational citizenship behavior as a pro-social behavior and state that the OCB includes the activities aimed at the establishment of both employee's prosperity and ease in his own business.

According to Organ and Konovsky (1989), OCB is the behaviors that affect the image and prestige of an organization in a positive way and increases cooperation and establish a unity in an organization and these behaviors are within the category of Spontaneous Behavior (Aslan, 2008:166). These definitions in the historical process summarized above are not sufficient to make a research on the organizational citizenship behavior in its all aspects; they even contain some controversial differences. For example, no award or punishment is in question in the organizational citizenship behaviors; however, in the spontaneous behaviors, there is an award or punishment (Kaynak, 2007:25). Moreover, in the organizational citizenship behaviors, the main objective is to favor the interests of all the organization and become fair to the members of all the organization; while in the pro-social behaviors, the justice behavior is destroyed because of the maintenance of specific members of the organization (Samanc1, 2007: 17).

Bateman and Organ (1983, p, 588) define the organizational citizenship behavior as the "behavior that is directly not included in the job description but is in favor of the social objective of the organization including the attitudes of the members of the organization (which are generally ignored). Organ (1988:4), in his another definition, states that the organizational citizenship behavior is the behaviors that are not directly or explicitly defined in the award system and is the individual behaviors that help the organizational functions be implemented efficiently as a whole."

\section{The Context of Organizational Citizenship Behavior}

In an organization, the organizational citizenship behaviors can basically be explained in two ways: (Özdevecioğlu, 2003: 119; Basım and Şeşen, 2006: 85):

The case when the members of an organization take active part in the organization by contributing to the organizational structure, applications and targets,

Or the case when the members of an organization keep away from any kind of activities against the interests of the organization. 
Yeşiltaş Etc. (2011:172) states that the studies on OCB can be classified in two groups; the studies on "job satisfaction, organizational commitment, leadership and duties" make up the first group and the studies on "the OCB and indicators of performance in an organizational level" form the second group.

Under the thumb of the definitions made we observed that there are no objective criteria like organizational citizenship behavior has universal consent lines composed of standardized profile or like law and organization norms; however there are manners shaped under the request of the members of organizations which is generated by individual initiative. By narrowing down this broad framework Greenberg and Baron (2000,p. 373) based OCB on these three key features:

The situation when the member of an organization acts in a particular manner which is more than expected plus what is stated in the job definition.

It is done voluntarily.

Getting into the act, without any award or penal sanctioning in return.

In addition to what is stated above, Topaloğlu (2005: 36) mentioned that the OCB provides evident benefits to the organization and the behavior shown within this context are conducts geared towards members of the organization or the organization itself. Organizational loyalty, individual's state of mind, personal traits, stance towards the job and job satisfaction, organizational justice, requirements of the organization members, qualities of the leader position and the hierarchical order, organizational vision, organization's vision, features of the organization and the union the of the individual and the organization are such important features aiding the creation and the development of the OCB (Karaman ve Aylan, 2012: 41-44).

\section{Dimensions of Organization Citizenship Behavior}

The concept of organization citizenship behavior which is contributed to academic literature by Organ (1988: 7-13) will be examined under five dimensions (Bolat etc., 2009: 218):

Altruism: It is the mutualization of an organization member with another organization member in business or in internal problems. Dimension of altruism also includes the guidance of an organization member who falls apart or compels to succeed (Sezgin, 2005: 323). While altruism enables new employee to easily adapt to the group and helps to increase the performance in parallel to the other members, it also simplifies the intergroup coordination leaving a positive mark on the general performance (Oğuz, 2011: 381).

Conscience (Sense of Duty): It is employee's showing voluntary behavior again outside the liable job definition. In this extent the organization member, with the goal of increasing the organization's performance, commits to voluntary, creative and reformist actions, convincing the other organization members around in taking extra responsibility (Köse vd. , 2003:5).

Gentlemanliness (Sportsmanship): This dimension includes having an indulgent manner rather than adopting a complaint manner regarding the problems taking place in the business. This one helps group 
members to put in magnificent performance (Oğuz, 2011: 381). As we frequently stated below this dimension, Podsakoff Vd. (2000: 517) takes attention to the inefficiency of complaining and the necessity putting the personal opinions away in bad times of the organization by thinking that uncomplaining will be misconceived. Plus that, he emphasizes that more self sacrifices shown by adopting good manner is the key of the situation.

Courtesy: Organization members, because of their vocation, have to be neat in not affecting other employees negatively, inform others before a problem occurs, be a reminder and transfer information and establish a strong communication, all which are in this behavioral dimension. According to Özdevecioğlu (2003: 121), the extent of courtesy expresses the positive communication between the individuals who make a division of labor within the organization.

Civic Virtue: It is the act of embracing the business as family, feeling individualistic responsibility in events interesting the organization and presenting an active, voluntary commitment, owing to the aforesaid responsibility principle, to the meetings and the gatherings made for solving the issue. According to George and Brief (1992) employee funding his/her personal development by self, without the consideration of expense, will show civic virtue which is an extension of the OCB (Ackfeldt \& Cote, 2003: 153).

\subsection{Concept of Organizational Justice}

The organizational justice is about the existence of punishment and reward system, its quality and the way of dispersal in the organization ((Robbins, 1988: 206):). It analyzes the degree of effect of punishment and reward on performance and efficiency. The sources of the organizational justice can be listed as fair distribution that deals with the fairness of the results employees gather; fair treatment used when giving a decision to specify what is obtained and fair interaction that is about the fair perception interpersonal communication (Yildirım, 2007: 256).

Arslantaş $(2007$, p.84) defends that it is necessary for organization leaders to act fairly to all organization members and to distribute sources fairly even though leaders show different levels of interest to the members. Decisions taken of administration, duties given and the attitude shown by administration and the behaviors whether they are fair or unfair, a perception is formed among the employees against the organization (Greenberg, 1990: 399). However Bies and Shapiro in their research state that if the decision makers are able to come up with a reasonable statement regarding the work they do and the procedures they adopt, their decisions are believed to be just even when negativity may arise (1987) (Çelik, 2007: 179).

Blau's (1964) Social Exchange Theory is one of the leading theories which sets up a speculative substructure of organizational justice. According to this theory there is a social exchange between the executives and the organization members based on trust and sincerity and that the organization members expect several rewards in return for their effort, decision and physical power they show for the good of the organization (Gürbüz, 2006: 53-54). Blau (1964) underscores that the satisfaction of mutual expectations 
what is mentioned in the social exchange theory have positive effects on reaching the goals of the organization (Katrinli etc., 2009: 376). Another theory which has similarity and is put forward out of the social exchange theory is the Leader-Member Exchange Theory, that deals with the idea there is satisfaction and content in the mutual expectations of executives and their subordinates (Ilies etc. 2007: 269).

Adams' (1965) Equity Theory stresses the organizational justice, stating that the organization members if thinking that they are not being treated equally or feel they are left out of reach from some resources, might not show the desired behavior but rather steer toward opposite direction (Yener \& Akyol, 2009: 257).

\subsection{Relationship between Organizational Justice and Organizational Citizenship Behavior}

If organization members have perception of positive justice, in other words if they think there is fair distribution and fair management it increases the adherence to an organization, enhance efficiency and performance (Karaman \& Aylan, 2007, p.42). Moreover when organization members are encountered with unfair treatment, motivation of the member will be negatively affected; therefore, the ratio of acting in organizational citizenship behavior decreases.

Dittrich \& Carroll (1979), Konovsky \& Folger (1991) and Farh etc., (1990) and Organ (1988, 1990) point out on their studies a direct connection between the judicial perception and the OCB (Moorman, 1991: 856). Organ (1983) states that organizational justice affects the OCB's gentlemanliness, politeness and the conscience dimensions; Haworth \& Levy (2001) on the other hand, state that while it affects OCB generally, altruism and conscience come into prominence a bit more; whereas Deluga (1994) argues the organizational justice in general affects the whole dimensions of the OCB, especially conscience the most and altruism the least; as for Schappe (1998) the organizational justice affects the dimensions of courtesy, conscience and gentlemanliness (Çelik, 2007: 180-181).

At certain times when employees feel the unfairness they refrain to act in OCB and conversely at certain times when they feel fairness they act in OCB (Moorman, 1991: 854; Köse etc., 2003: 12). Additionally the situation of making an unmerited concession or allowing an executive to take up an unmerited higher position in an offending way toward employees hampers the act of OCB in organizations (Çelik, 2007: 166).

When the decision taken are explained reasonably with also forming an effective communication, the employees by feeling themselves valuable and secure, affect the conscience dimension (Çelik, 2007: 182). Niehoff ve Moorman (1993: 528) defend that this negative understanding toward OCB stemming from the close performance inspections, which in general negatively influences the showing of OCB, would be removed if the executives convince the employees that this is a part of their jobs and act fair to everyone in the organization. 
In the literature search, the findings related to the relationship between OCB and organizational justice and their degree of effects creates the goal of research as it is a significant subject among organizations and employees. Hypotheses developed by the given literature knowledge is as listed below:

H1: When the employees' perception of organizational justice rises, the OCB increases.

H1a: When the employees' perception of organizational justice rises, altruist behavior increases.

H1b: When the employees' perception of organizational justice rises, conscience behavior increases.

H1c: When the employees' perception of organizational justice rises, courtesy increases.

H1d: When the employees' perception of organizational justice rises, gentlemanliness increases.

$\mathrm{H} 2$ : Organizational justice meaningfully influences the showing of OCB.

H2a: Organizational justice meaningfully influences the showing of altruist behavior.

$\mathrm{H} 2 \mathrm{~b}$ : Organizational justice meaningfully influences the showing of conscience.

$\mathrm{H} 2 \mathrm{c}$ : Organizational justice meaningfully influences the showing of courtesy.

H2d: Organizational justice meaningfully influences the showing of gentlemanliness.

H2e: Organizational justice meaningfully influences the showing of civic virtue.

\section{Methodology}

While some organization researchers assert that the organizational culture can not be measured by quantitative methods, but has to be scrutinized by qualitative methods such as observation and interview; whereas some others are supporters of quantitative methods to be used in organizational culture studies (İpek, 1999: 415). The methodology of this quantitative research is fieldwork on organizational justice and organizational citizenship behaviors. Primary sources are compiled with pre-prepared survey method and with the technique of posing written questions.

\subsection{Data Collection}

In the research a survey has been implemented at a textile facility in Osmancık region of the city of Çorum. It has been projected this research universe has $95 \%$ reliability with a $5 \%$ margin of error foreseen, the sample has been calculated as 110 out of a universe of 153 people (The Survey System, 2012). Although the sample is measured in 110 people, for the survey to represent the universe on a larger scale, 126 of the employees' surveys were taken into consideration out of the sum of 129 (sample ratio \% 84), due to the wrong and incomplete markings. 
The question of gender is removed from the survey considering that almost all employees are women. The business employees have been informed on the matter that the answers they will be responding to the questions of the survey will be used within the context of the research and their names-surnames will not be written on the questionnaires.

The fact that the business employees accounting for the majority of the subjects, taking part in the survey, is assumed to reflect the organizational justice and the OCB relationship completely. Beyond that it is assumed that the survey will deduce to what extent organizational justice affects the OCB and its dimensions. It is also presupposed that the participants understood the content correctly; they were objective and realistic; they sincerely gave the most convenient answers.

\subsection{Data Analysis}

The survey starts with demographical questions. The OCB survey scale is composed of 20 questions which is laid down by Podsakoff and Mackenzie and improved by Çelik (2007: 198). The scale is composed of five dimensions; each scale is made up of 4 questions. During the field research method of organizational justice scale which is prepared by Niehoff and Moorman (1993) and improved by Ylldırım (2007) has been used. Research hypotheses and questionnaires have been formally submitted by experts; after the correction of inadequacies the survey has been applied. Employees, whom at times gather as groups and at times as individuals were asked to fill the survey.

Organizational justice scale and the OCB scale have been adapted to Likert's typical five-level item and the scoring is identified as: (5) "Strongly Agree", (4) "Agree", (3) "Neither Agree nor Disagree", (2) "Disagree" and (1) "Strongly Disagree". İşcan (2002 184) the raised scale by Likert's journal titled A Technique for the Measurement of Attitudes (1932) which is reinforced by Spearman's Theory of Factors, states that individuals are expected to react to the developed theses about the subject and show the degree of acceptance to each thesis.

As it is demonstrated in the Table 1; with the result of reliability analysis of organizational justice, composed of 20 features organization culture scale's Cronbach Alpha value was found 0,961 and the conclusion was made of the scale being highly reliable.

Table 1. Reliability Result of Organizational Justice Scale

\begin{tabular}{|lccc|}
\hline & $\begin{array}{l}\text { Number of } \\
\text { Articles }\end{array}$ & $\begin{array}{l}\text { Cronbach } \\
\text { Alpha Value }\end{array}$ & Result of Reliability \\
\hline Organizational Justice & 20 & 0,961 & Reliability of High Level \\
\hline
\end{tabular}

As it is demonstrated in the Table 1; with the result of reliability analysis of organizational justice, composed of 20 features organization culture scale's Cronbach Alpha value was found 0,961 and the 
conclusion was made of the scale being highly reliable. On the OCB levels, with the result of the reliability analysis, altruism is find to be highly reliable and the other dimensions substantially reliable.

Table 2. Organizational Citizenship Behavior Scale and Results of Sub-dimensions

\begin{tabular}{|lccc|}
\hline & \multicolumn{2}{c|}{$\begin{array}{c}\text { Number of Cronbach } \\
\text { Articles }\end{array}$} & $\begin{array}{c}\text { Alpha Value } \\
\text { Reliability }\end{array}$ \\
\hline Organizational Citizenship Behavior & 20 & 0,914 & Reliability of High Level \\
Altruism & 4 & 0,829 & Reliability of High Level \\
Consciousness or Sense of Mission & 4 & 0,766 & Reliability of Fair Level \\
Courtesy & 4 & 0,737 & Reliability of Fair Level \\
Gentlemanliness & 4 & 0,693 & Reliability of Fair Level \\
Civic Virtue & 4 & 0,740 & Reliability of Fair Level \\
\hline
\end{tabular}

\section{Findings}

\subsection{Demographical Findings}

According to the Table 3 majority of this facility's employees are aged between 25 and 45 . Generally speaking, the facility is a place composed of young employees. Workers who are above 45 are situated in cleaning, catering, gardening departments.

Table 3. Distribution the Employees as Per Their Age Groups

\begin{tabular}{|lcc|}
\hline \multicolumn{1}{|c}{ Age Group } & $\begin{array}{c}\text { Number of } \\
\text { People }\end{array}$ & Percentage \\
18-24 year-old & 10 & 7,9 \\
25-34 year-old & 47 & 37,3 \\
35-44 year-old & 43 & 34,1 \\
45 year-old or more & 26 & 20,6 \\
Total & $\mathbf{1 2 6}$ & $\mathbf{1 0 0}$ \\
\hline
\end{tabular}

In this facility labor is in the foreground rather than academic education. According to the Table 4, majority of the workers are primary school graduates, underscoring the fact that work experience is held in priority rather than education level.

Table 4. Distribution the Employees as Per Their Educational Levels

\begin{tabular}{|ccc|}
\hline Educational Level & Number of People & Percentage \\
Primary School & 88 & 69,8 \\
High School/College & 38 & 30,2 \\
Total & $\mathbf{3 9 3}$ & $\mathbf{1 0 0}$ \\
\hline
\end{tabular}


Skilled laborers are required in this business. At least two years of experience is needed to become a productive worker. The information given at Table 5 shows $80 \%$ of the workers have experience of 6 years and higher.

Table 5. Distribution the Employees as Per Their Professional Experience

\begin{tabular}{|c|c|c|}
\hline Professional Experience & $\begin{array}{l}\text { Number of } \\
\text { People }\end{array}$ & Percentage \\
\hline 1-5 Years & 30 & 23,8 \\
\hline 6-10 Years & 55 & 43,7 \\
\hline 11 Years or more & 41 & 32,5 \\
\hline Total & 126 & 100 \\
\hline
\end{tabular}

\subsection{Results of the Correlation Analysis}

Pearson Correlation Analysis is a method used for analyzing variable to variable proportionally, eligibility of a connection in the same path or the opposite and to show its degree and direction. If there is no connection between two variables it gets the value $r=0$, if two variables are in the same path it becomes $r(+)$ and if there is an opposite directed connection between two variables it takes the $\mathrm{r}(-)$ value (Archdeaco, 1994:98-100; Cooper and Weekes, 1983:10). Pearson Correlation Analysis has been conducted to find out about how the employees' organizational perception increases or decreases the OCB and its levels. When it is carefully observed it becomes evident that there is a positive connection between the organizational justice and the OCB with its dimensions.

Table 6. The relationship between Organizational Justice Scale and Organizational Citizenship Behavior Scale and its sub-dimensions (Correlation Analysis)

\begin{tabular}{|c|c|c|c|c|c|c|c|}
\hline & 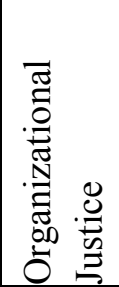 & 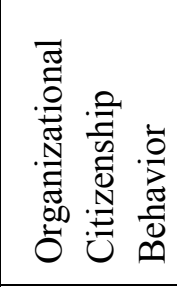 & 昜 & $\begin{array}{l}0 \\
0 \\
0 \\
0 \\
0 \\
0 \\
0 \\
0 \\
0 \\
0\end{array}$ & 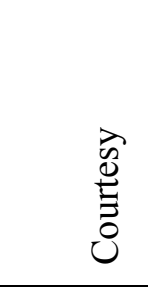 & 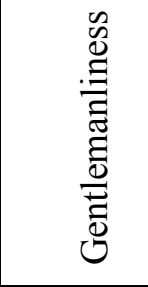 & 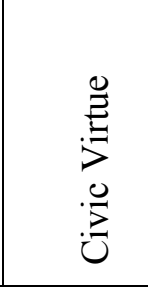 \\
\hline $\begin{array}{l}\text { Organizational } \\
\text { Justice }\end{array}$ & 1,000 & $0,476 * *$ & $0,439 * *$ & $0,426 * *$ & $0,390 * *$ & $0,365 * *$ & $0,450 * *$ \\
\hline $\begin{array}{l}\text { Organizational } \\
\text { Citizenship } \\
\text { Behavior }\end{array}$ & & 1,000 & $0,897 * *$ & $0,917 * *$ & $0,880 * *$ & $0,886^{* *}$ & $0,889 * *$ \\
\hline Altruism & & & 1,000 & $0,783 * *$ & $0,715^{* *}$ & $0,749 * *$ & $0,743 * *$ \\
\hline Consciousness & & & & 1,000 & $0,807 * *$ & $0,769 * *$ & $0,771 * *$ \\
\hline Courtesy & & & & & 1,000 & $0,696^{* *}$ & $0,732 * *$ \\
\hline Gentlemanliness & & & & & & 1,000 & $0,751 * *$ \\
\hline Civic Virtue & & & & & & & 1,000 \\
\hline
\end{tabular}




\subsection{Results of the Regression Analysis}

Regression analysis is a statistical process for estimating the relationship among variables. It tries to explain relations and cause and effect situations between a dependant and independent variables (Freund etc., 2006: 36-37). Besides, in this research during regression analysis, Durbin-Watson (DW) test was also used. As Akgün and K1lıç (2013: 32) explain in their latest research, there mustn't be an antocorrelation between dependant and independent variables and residuals or error chains mustn't have correlations and the errors in data set must be dependant. To question this situation Durbin-Watson (DW) test must be used. In Durbin-Watson (DW) test if the test value between 1,5-2,5 shows that there is no autocorrelation between variables (Kalayc1, 2005: 265).

Tablo 7. The Affect Result of the Citizenship Behavior by the Organizational Justice among the Employees in the Business (Regression Analysis)

\begin{tabular}{|llll|}
\hline Independent Variables & B Value & T & P \\
\hline Stable Organizational & 2,797 & 12,028 & $\mathbf{0 , 0 0 0 * *}$ \\
Justice & 0,485 & 6,028 & $\mathbf{0 , 0 0 0 * *}$ \\
\hline Corrected $\mathrm{R}^{2}$ & 0,227 & & \\
F & 36,333 & & \\
P & $0,000^{*}$ & & \\
Durbin-Watson & 1,878 & & \\
\hline
\end{tabular}

As it seen in Table 7; organizational justice explains $\% 22,7$ of organizational citizenship behaviors. In other words, organizational justice has positive and meaningful effects on organizational citizenship behavior. Besides, Durbin-Watson (DW) test shows there's no autocorrelation between dependant and independent variables as the test value is 1,878 .

Table 8. The Affect Result of the Altruism Behavior by the Organizational Justice among the Employees in the Business (Regression Analysis)

\begin{tabular}{|llll|}
\hline Independent Variables & B Value & T & P \\
\hline Stable & 2,573 & 8,785 & $\mathbf{0 , 0 0 0 * *}$ \\
Organizational Justice & 0,551 & 5,443 & $\mathbf{0 , 0 0 0 * *}$ \\
\hline Corrected $\mathrm{R}^{2}$ & 0,193 & & \\
F & 29,627 & & \\
P & $0,000^{*}$ & & \\
Durbin-Watson & 1,887 & & \\
\hline
\end{tabular}


As it seen in Table 8, organizational justice explains \%19,3 of altruism. In other words, organizational justice has meaningful effects on organizational citizenship behaviors. Besides as the Durbin-Watson (DW) test has the value of 1,887 , we can say that there's no autocorrelation between dependant and independent variables.

Table 9. The Affect Result of the Consciousness Behavior by the Organizational Justice among the Employees in the Business (Regression Analysis)

\begin{tabular}{|llll|}
\hline Independent Variables & B Value & T & P \\
\hline Stable & 2,961 & 12,146 & $\mathbf{0 , 0 0 0 * *}$ \\
Organizational Justice & 0,441 & 5,238 & $\mathbf{0 , 0 0 0 * *}$ \\
\hline Corrected ${ }^{2}$ & 0,181 & & \\
F & 27,440 & & \\
P & $0,000^{*}$ & & \\
Durbin-Watson & 2,059 & & \\
\hline
\end{tabular}

In Table 9 it's seen that organizational justice explains $\% 18,1$ of conscientiousness. In other words organizational justice has meaningful effects on organizational citizenship behaviors. Besides as the Durbin-Watson (DW) test has the value of 2,059, we can say that there's no autocorrelation between dependant and independent variables.

Table 10. The Affect Result of the Courtesy Behavior by the Organizational Justice among the Employees in the Business (Regression Analysis)

\begin{tabular}{|llll|}
\hline Independent Variables & B Value & T & P \\
\hline Stable & 3,023 & 10,957 & $\mathbf{0 , 0 0 0 * *}$ \\
Organizational Justice & 0,450 & 4,715 & $\mathbf{0 , 0 0 0 * *}$ \\
\hline Corrected $\mathrm{R}^{2}$ & 0,152 & & \\
F & 22,233 & & \\
P & $0,000^{*}$ & & \\
Durbin-Watson & 2,142 & & \\
\hline
\end{tabular}

As it seen in Table 10, organizational justice explains \%15,2 of courtesy of behavior. In other words, organizational justice has meaningful effects on organizational citizenship behaviors. Besides as the Durbin-Watson (DW) test has the value of 2,142, we can say that there's no autocorrelation between dependant and independent variables. 
Table 11. The Affect Result of the Gentlemanliness Behavior by the Organizational Justice among the Employees in the Business (Regression Analysis)

\begin{tabular}{|llll|}
\hline Independent Variables & B Value & T & P \\
\hline Stable & 2,933 & 11,258 & $\mathbf{0 , 0 0 0 * *}$ \\
Organizational Justice & 0,394 & 4,372 & $\mathbf{0 , 0 0 0 * *}$ \\
\hline Corrected $\mathrm{R}^{2}$ & 0,134 & & \\
F & 19,118 & & \\
P & $0,000^{*}$ & & \\
Durbin-Watson & 1,826 & & \\
\hline
\end{tabular}

As it seen in Table 11, organizational justice explains \%13,4 of sportsmanship. In other words, organizational justice has meaningful effects on organizational citizenship behaviors. Besides as the Durbin-Watson (DW) test has the value of 1,826 , we can say that there's no autocorrelation between dependant and independent variables.

Table 12. The Affect Result of the Civic Virtue Behavior by the Organizational Justice among the Employees in the Business (Regression Analysis)

\begin{tabular}{|llll|}
\hline Independent Variables & B Value & T & P \\
\hline Stable & 2,736 & 10,505 & $\mathbf{0 , 0 0 0 * *}$ \\
Organizational Justice & 0,505 & 5,605 & $\mathbf{0 , 0 0 0 * *}$ \\
\hline Corrected $\mathrm{R}^{2}$ & 0,202 & & \\
F & 31,420 & & \\
P & $0,000^{*}$ & & \\
Durbin-Watson & 1,752 & & \\
\hline
\end{tabular}

In Table 12, it's seen that organizational justice explains $\% 20,2$ of civil virtue. In other words, organizational justice has meaningful effects on organizational citizenship behaviors. Besides, DurbinWatson (DW) test shows there's no autocorrelation between dependant and independent variables as the test value is 1,752 .

\section{Implications}

The main aim in organizational citizenship behaviors is to protect the all benefits of the organization and to be just to all the members of the organization (Samanc1, 2007: 17). Being fair during the decision process in the organization, having an equal behavior habits and distributing the sources equally both harden the 
commitment of the members to the organization and increases the presence of the organizational citizenship behaviors.

Among preconditions justice perception of the organization members reserve an important place (Aryee etc., 2002: 269). In such a way that, distributing the sources equally and being just among employees are very important factors for developing of organizational citizenship behaviors. As Basım and Şeşen (2009: 813) mention; organization members perception of organizational justice effects them either to expose organizational citizenship behaviors or not.

As it seen in Table 6 gives the results of correlation analysis, there is a meaningful relationship between organizational justice and organizational citizenship behaviors $(r=0,476, p<0,05)$. In the direction of the findings in Table 6; $\mathrm{H} 1$ and its sub hypothesis are accepted. According to the data in Table 6; as the perception of organizational justice rises altruism $(r=0,439, p<0,05)$, conscientiousness $(r=0,426, p<0,05)$, courtesy ( $r=0,390, p<0,05)$, sportsmanship $(r=0,365, p<0,05)$ and civil virtue $(r=0,450, p<0,05)$ behaviors also rise. Towards the results, when organizational justice rises, most civil virtue and least sportsmanship does so.

In the regression analysis, the positive effects of organizational justice on organizational citizenship behaviors and on its dimensions are retained. As seen; it's obvious that on Table 7, organizational justice explains $\% 22,7$ of organizational citizenship behaviors, on Table $8 \% 19,3$ of altruism, on Table $9 \% 18,1$ of conscientiousness, on Table $10 \% 15,2$ of courtesy, on Table $11 \% 13,4$ of sportsmanship, on Table 12 $\% 20,2$ of civil virtue. Results of the regression analysis show that; organizational justice interprets both organizational citizenship behaviors and its dimensions. Organizational justice explains civil virtue most and sportsmanship behaviors least. In the light of the results given above, H2 and its sub hypothesis are accepted. During the literature research; it's seen that besides the effects of organizational justice on organizational citizenship behaviors and on its dimensions there are other factors that has an effect like employees' personal qualities, psychosocial statue, job satisfaction, organizational commitment, communication skills, motivation and other specific factors related to organization.

As it's mentioned before organizational citizenship behaviors are done without any expectations and they are useful for the organization and other employees. However, Chompookum \& Derr (2004: 406) express that a person shows organizational citizenship behaviors expects to be realized; have physical or spiritual awards. Due to this psychological determination, it can be said that although organization members do these behaviors voluntarily, administrators have to use methods and awards to keep these behaviors' persistence. These kinds of attitudes make employees not to have negative emotions to their organizations and will lead the employees to show positive and useful behaviors (Blakely etc., 2005: 259).

As it's mentioned repeatedly before responding to organizational citizenship behaviors with an award, hardens these behaviors and has an encouraging role among other employees. The belief in having on 
award or promotion and trust in a justice management make employees to show organizational citizenship behaviors voluntarily (Çelik, 2007: 179). Encouraging award system is related to the culture of the social structure that feeds the organization. Namely, in western societies individual life understanding is common so it is an questioning situation that a person shows some behaviors without an expectation of benefit. Relying on this, Köse etc. (2003: 11-12) express that for an employee living in a western society award is an encouraging effect but in Eastern societies which seek profit of collectivism, fidelity and protection understanding is important so award system must be built for the group not for the individuals.

\section{Conclusions}

Organizational justice and organizational citizenship behaviors are an area examined by different disciplines. The main aim of this research is finding the sources of desired behaviors and explaining the effective factors of them. In this study, the relationship and relationship level of organizational justice with organizational citizenship behaviors and its dimensions are examined. As the result of the analysis, the relationship between the organizational justice and the organizational citizenship behaviors and with its dimensions is meaningful. When the perception of organizational justice rises, presence of organizational citizenship behaviors evenly does, too.

A fair working environment, being just to employees, distributing of awards and punishments equally cause a motivating and increase effect on the presence of these designed but not compulsory behaviors. Increasing of organizational citizenship behaviors makes a great deal of benefits for the organizations to achieve their aims and goals.

Finally, this research has been carried out in a textile firm in the city of Çorum and; in order to make a generalization it's good to study this research on wider samples. By using different questions, methods, wider samples as even different sectors will decrease the limitations and contribute to the academic knowledge of organizational justice and organizational citizenship behaviors. Besides, using the variables like organizational commitment, job satisfaction and motivating in a foresaid researches will undoubtly enrich the new studies.

\section{References}

Ackfeldt, A.L .\& Cote, L.V. (2003), "A Study Of Organizational Citizenship behavior In A Retail Setting", Journal of Business Research, 58,151 - 159.

Adams, J. S. (1965), "Inequity In Social Exchange”, L. Berkowitz (Ed.) Advances in Experimental Social Psychology, Vol.2, pp. 267-299. New York: New York Academic Press.

Akgün, A. İ. ve Kılıç, S.(2013),"Muhasebe Bilgi Sisteminin İşletme Yönetiminin Etkinliği Üzerindeki Etkisi", Celal Bayar Üniversitesi İ.İ.B.F. Yönetim ve Ekonomi dergisi, 20(2), 21-36.

Archdeaco T. J.(1994). Correlation \& Regression Analysis: A Historian's Guide. Madison: The University of Wisconsin Press.

Argyris C. (1960). Understanding Organizational Behavior. Homewood, IL: Dorsey Press. 
Aryee, S., Budhwar, P. S. and Chen, Z. X. (2002),“Trust As A Mediator Of The Relationship Between Organizational Justice And Work Outcomes: Test of A Social Exchange Model”, Journal of Organizational Behavior, 23, 267-285.

Arslantaş, C.C. (2007), "Dönüşümcü Liderliğin Psikolojik Güçlendirme ve Örgütsel Vatandaşlık Davranış1 Üzerindeki Etkisi”, Amme İdaresi Dergisi, 40(4), ss. 81-101.

Aslan, Ş.(2008),“Örgütsel Vatandaşlık Davranışı ile Örgütsel Bağlılık ve Mesleğe Bağl1lık Arasındaki İliskilerin Araştırılması", Celal Bayar Üniversitesi İktisadi ve İdari Bilimler, Yönetim ve Ekonomi Dergisi, 15(2), ss. 163-178.

Blau, P. (1964). Exchange And Power In Social Life, New York: John Wiley \& Sons.

Brief, A.P. and Motowidlo, S.J. (1986), "Prosocial Organizational Behaviors”, Academy of Management Review, 11(4), 710-725.

Basım, H.N. ve Şeşen, H.(2009). "Örgütsel Adalet Algısı-Örgütsel Vatandaşlık Davranışı İlişkisinde İş Tatmininin Aracilık Rolü”. 17. Ulusal Yonetim ve Organizasyon Kongresi Bildiriler Kitabı, 21-23 Mayıs 2009, ss.808-814. Eskişehir: Eskişehir Osmangazi Üniversitesi İktisadi ve İdari Bilimler Fakültesi İşletme Bölümü.

Bateman, T.S. and Organ, D. W. (1983),"Job Satisfaction and The Good Soldier: The Relationship Between Affect And Employee Citizenship", Academy of Management Journal, 26, 587-595.

Bies, R. J., and Shapiro, D. L. (1987), “' Interactional fairness judgments: The influence of causal accounts",Social Justice Research, 1, 199-218.

Blakely G. L., Srivastava A. and Moorman R. H. (2005), "The Effect Of OCB”, Journal of Leadership and Organizational Studies, 12(1), 103-117.

Blau, P. (1964). Power and exchange in social life. NY: John Wiley \& Sons.

Bolat O. İ., Bolat T. ve Seymen Aytemiz O. (2009),“Güçlendirici Lider Davranısları ve

Örgütsel Vatandaslık Davranısı Arasındaki İlişkin Sosyal Mübadele Kuramından Hareketle İncelenmesi”, Balıkesir Üniversitesi Sosyal Bilimler Enstitüsü Dergisi, 12( 21), 215-239.

Chompookum, D. and Derr, C. B. (2004),"The Effects Of Internal Career Orientations On Organizational Citizenship Behavior In Thailand", Career Development International, 9(1),406-423.

Cooper, R. A. ve Weekes, T. J.(1983). Data, Models, And Statistical Analysis. Totowa: Barnes And Nobles Books

Coyle-Shapiro, J.A-M and Parzefall, M-R. (2008),"Psychological contracts", In C.L. Cooper \& J. Barling (Eds.) Handbook of Organizational Behavior,(ss.17-34). Thousand Oaks, CA: Sage.

Çekmecelioğlu, H.G. ve Keleş, Ö(2009), “Örgüt İklimi, Örgütsel Vatandaşlık Davranışı ve İş Performansı Arasındaki İlișkilerin İncelenmesi: Bir Araştırma”.17. Ulusal Yonetim ve Organizasyon Kongresi Bildiriler Kitabı. 21-23 Mayıs, ss.590-597. Eskişehir: Eskişehir Osmangazi Üniversitesi İktisadi ve İdari Bilimler Fakültesi İşletme Bölümü.

Çelik, M. (2007), Örgüt Kültürü ve Örgütsel Vatandaşlık Davranışı - Bir Uygulama. (Yayınlanmamış Doktora Tezi).Erzurum: Atatürk Üniversitesi Sosyal Bilimler Enstitüsü

Danaeefard H., Balutbazeh A.E. and Kashi K.H.A (2010), “Good Soldiers' Perceptions Of Organizational Politics Understanding The Relation Between Organizational Citizenship Behaviors And Perceptions Of Organizational Politics: Evidence From Iran", European Journal of Economics, Finance and Administrative Sciences, 18, 146-162

Dansereau F., Graen G., and Haga W. J. (1975), “A Vertical Dyad Approach to Leadership within Formal Organizations", Organizational Behavior and Human Performance, 13, 4678. 
Deluga, R.J. (1994),"Supervisor Trust Building, Leader-Member Exchange And Organizational Citizenship Behaviour" Journal of Occupational and Organizational Psychology, 67, 315-326.

Demirel, Y.( 2009), “Örgütsel Bağlılık ve Üretkenlik Karşıtı Davranışlar Arasındaki İlişkiye Kavramsal Yaklaşım”, Istanbul Ticaret Üniversitesi Sosyal Bilimler Dergisi, 8(15), 115-132.

Ditrich, J.E. and Carel, M.R. (1979), “ Organizational equity perceptions, employejob satisfaction, and departmental absence and turnover rates", Organizational Behavior and Human Performance, , 24, $29-40$.

Farh J., P., Earley C., and Lin, S.(1997),"Impetus For Action: A Cultural Analysis Of Justice And Organizational Citizenship Behavior In Chinese Society", Administrative Science Quarterly, 42(3), 421-444.

Finkelstein, M. A. and Penner, L. A. (2004) " Predicting Organizational Citizenship Behavior: Integrating the Functional and Role Identity Approaches." Social Behavior and Personality, 32, 383-398.

Fodchuk, K.M. (2007),“Work Environments That Negate Counterproductive Behaviors And Foster Organizational Citizenship: Research-Based Recommendations For Managers", The PsychologistManager Journal, 10 (1), 27-46.

Folger, R., and Konovsky, M. A. (1989), "Effects of procedural and distributive justice on reactions to pay raise decisions", Academy of Management Journal, 32, 115 - 130.

Freund R.J., Wilson W. J ve Sa, P. (2006). Regression Analysis. Burlington: Academic Press

George, Jennifer M. (1991) " State or trait: Effects of positive mood on prosocial behaviors at work ”, Journal of Applied Psychology, 76(2), 299-307.

George, J. M., and Brief, A. P. (1992),“ Feeling good-doing good: A conceptual analysis of the mood at work-organizational spontaneity relationship”, Psychological Bulletin, 112, 310-329.

George J.M. and Jones, G.R. (1997), “ Organizational Spontaneity In Context”, Human Performance, 10(2), 153-170.

Goodman, S. A. and Svyantek, D. J. (1999),“ Person-organization fit and contextual performance: Do shared values matter?", Journal of Vocational Behavior, 55, 254-275.

Gouldner, A.W. (1960), “The Norm Of Reciprocity: A Preliminary Statement”, American Sociological Review, 25, 161-178.

Greenberg, J. (1990),“Organizational Justice: Yesterday, Today, And Tomorrow” Journal of Management, 16, 399-432.

Greenberg, J. and Baron, R.A. (2000). Behavior In Organizations (Seventh Edition). Upper Saddle River: Prentice Hall.

Gürbüz, S. (2006), “Örgütsel Vatandaşlık Davranışı ile Duygusal Bağlılık Arasındaki İlişkilerin Belirlenmesine Yönelik Bir Araştırma”, Ekonomik ve Sosyal Araştırmalar Dergisi, 3(1) , 48-75.

Haworth, C. L. and Levy, P. E. (2001) "The İmportance Of Instrumentality Beliefs In The Prediction Of Organizational Citizenship Behaviors”, Journal of Vocational Behavior, 59(1), 64-75.

Ilies, R., Nahrgang, J. D. and Morgeson F. P.( 2007), "Leader-Member Exchange And Citizenship Behaviors: A Meta-Analysis", Journal of Applied Psychology, 92(1), 269-277.

İşcan, Ö. F. (2002). Küresel İşletmecilikte Dönüştürücü Liderlik Anlayış̧1-Büyük Ölçekli İşletmelerde Bir Uygulama. (Unpublished PhD Dissertation). Erzurum: Atatürk Üniversitesi Sosyal Bilimler Enstitüsü.

Kalaycı, Ş. (2005), “Çoklu Doğrusal Regresyon Modeli”, Ş. Kalaycı (Ed:). SPSS Uygulamalı Çok Değişkenli İstatistik Teknikleri, ss. 259-266.. Ankara: Asil Yayın Dağıtım, 
Karaaslan, A., Özler, D. E., ve Kulaklığlu, A. E. (2009),“Örgütsel Vatandaşlık Davranışı ve Bilgi Paylaşımı Arasındaki İlişkiye Yönelik Bir Araştırma”, Afyon Kocatepe Üniversitesi, İktisadi ve idari Bilimler Fakültesi Dergisi, 11(2), 135-160.

Karaman, A. ve Aylan, S.(2012),“Örgütsel Vatandaşlık”, Kahramanmaraş Sütçü İmam Üniversitesi İktisadi ve İdari Bilimler Fakültesi Dergisi, 2(1), 35-48.

Karcıoğlu, F. ve Türker, E. (2010),"Psikolojik Sözleşme ile Örgütsel Bağlılık İlişkisi: Sağlık Çalışanları Üzerine Bir Uygulama”, Atatürk Üniversitesillktisadi ve idari Bilimler Dergisi, 24(2), 121-140.

Katrinli, A., Atabay,G., Günay, G. ve Çangarlı,B.G.(2009)."Lider Üye Arasındaki Etkileşimin Psikolojik Sözleşme İhlali ile Örgütsel Vatandaşlık İlişkisi Üzerindeki Düzenleyici Rolü”.17. Ulusal Yonetim ve Organizasyon Kongresi Bildiriler Kitabı. 21-23

Mayıs, ss.376-378. Eskişehir: Eskişehir Osmangazi Üniversitesi İktisadi ve İdari Bilimler Fakültesi İşletme Bölümü.

Katz, D. and R.L. Kahn (1978). The Social Psychology of Organizations. NewYork: John Wiley \& Sons.

Kaynak, S.(2007). Öğretmenlerin Kişilik Özellikleri ve Örgütsel Vatandaşlık Davranışı (Yayımlanmamış Yüksek Lisans Tezi). Afyon: Afyon Kocatepe Üniversitesi Sosyal Bilimler Enstitüsü Sınıf Ögretmenligi Anabilim Dalı.

Kotter, J. P. (1973), “The Psychological Contract: Managing The Joining-Up Process”, California Management Review, 15(3), 91-99.

Köse, S., Kartal, B. ve Kayalı, N.(2003),“Örgütsel Vatandaşlık Davranışı ve Tutuma İlişkin Faktörlerle İlişkisi Üzerine Bir Araştırma”, Erciyes Üniversitesi İktisadi ve İdari Bilimler Fakültesi Dergisi, 20 , 1-19.

Levinson .H, Price C, Munden K., Mandl H, and Sooley C. (1962). Men Management And Mental Health. Cambridge, MA: Harvard University Press.

Moorman R. H. (1991), "Relationship Between Organizational Justice And Organizational Citizenship Behaviors: Do Fairness Perceptions Influence Employee Citizenship?" Journal of Applied Psychology, 76(6), 845-855

Niehoff, B.P. and Moorman, R.H. (1993), "Justice As A Mediator Of The Relationship Between Methods Of Monitoring And Organizational Citizenship Behavior", Academy of Management Journal, 36 (3), 527-556.

Oğuz, E. (2011),“Öğretmenlerin Örgütsel Vatandaşlık Davranışları ile Yöneticilerin Liderlik Stilleri Arasındaki İlişki”, Kuram ve Uygulamada Eğitim Yönetimi Dergisi, 17(3), 377-403

Organ, D. W. (1988). Organizational Citizenship Behavior: The Good Soldier Syndrome. Lexington: Lexington Books.

Organ, D. W., and Konovsky, M. A. (1989) "“Cognitive versus affective determinants of organizational citizenship behavior", Journal of Applied Psychology, 74, 157-164

Özdevecioğlu, M. (2003),“Örgütsel Vatandaşlık Davranışı ile Üniversite Öğrencilerinin Bazı Demografik Özellikleri ve Akademik Başarıları Arasındaki İlişkilerin Belirlenmesine Yönelik Bir Araştırma”, Erciyes Üniversitesi İktisadi ve İdari Bilimler Fakültesi Dergisi, 20,117 - 135.

Özutku H., Ağca V. and Cevrioğlu, C(2008),"Lider-Üye Etkileşim Teorisi Çerçevesinde, Yönetici-Ast Etkileşimi İle Örgütsel Bağlılık Boyutları ve İş Performansı Arasındaki İlişki: Ampirik Bir İnceleme", Atatürk Üniversitesi İktisadi ve İdari Bilimler Fakültesi Dergisi, 22(2), 193-210.

Perçin, M.(2008). Öğemenliği Örgüt Yapısının İşgörenlerin Örgütsel Bağl1lığına Etkisine İlişkin Bir Araştırma. (Unpublished PhD Dissertation). Isparta: Süleyman Demirel Üniversitesi Sosyal Bilimler Enstitüsü. 
Podsakoff, P.M., MacKenzie, S.B., Paine, J.B. \& Bachrach, D.G. (2000),“Organizational Citizenship Behaviors: A Critical Review Of The Theoretical And Empirical Literaturen And Suggestions For Future Research", Journal of Management, 26(3), 513-563.

Rotter, J.B. (1966),“ Generalized Expectancies For Internal Versus External Control Of Reinforcement”, Psychological Monographs, 80, 1-28.

Rousseau, D. M. (1990), “New hire perceptions of their own and their employer's obligations: A study of psychological contracts", Journal of Organizational Behavior, 11, 389-400.

Rousseau, D.M. (1995). Psychological Contracts In Organizations: Understanding Written And Unwritten Agreements. Thousand Oaks, CA: Sage Publications.

Samancı, G. (2007). Örgütsel Güven ve Örgütsel Vatandaşlık Davranışı. (Yayınlanmamış Yüksek Lisans Tezi). Afyon: Afyon Kocatepe Üniversitesi Sosyal Bilimler Enstitüsü Sınıf Öğretmenliği Anabilim Dalı.

Schappe, S. (1998) "“The influence of Job Satisfaction, Organizational Commitment, and Fairness Perceptions on Organizational Citizenship Behavior", The Journal of Psychology, 132, 277-290.

Schein, E. H. (1965). Organizational Ppsychology. Englewood Cliffs: Prentice-Hall.

Sezgin, F. (2005),“ Örgütsel Vatandaşlık Davranışları: Kavramsal Bir Çözümleme ve Okul Açısından Bazı Çıkarımlar ”, Gazi Üniversitesi Gazi Eğitim Fakültesi Dergisi, 25(1), 317-339.

Smith, C. ,Organ D. W. and J. Near (1983),“'Organizational Citizenship Behavior: Its Nature And Antecedents", Journal of Applied Psychology, 68(4), 653-663.

Syed, S.(2009-2010). Impact of organizational restructuring on psychological contract breach and attitudes of employees working in private commercial banks of Pakistan (Unpublished PhD Dissertation). Enschede, Netherlands:University of Twente

Terzi A. R.(2011),“ Denetim Odağı ve Örgütsel Vatandaşlık Davranışı İlişkisi: Üniversite Öğrencileri Üzerinde Bir Araştırma”, Eğitim ve Bilim, 36(162), 3-15.

The Survey System(2012), Sample Size Calculator, Erişim Tarihi: 26 Ağustos 2014, http://www.surveysystem.com/sscalc.htm.

Yeşiltaş, M., Türkmen, F. ve Ayaz N.(2011),“Otel İşletmelerinde Algılanan Örgütsel Prestijin Örgütsel Vatandaşlık Davranışları Üzerindeki Etkileri”, Cumhuriyet Üniversitesi İktisadi ve İdari Bilimler Dergisi, 12( 2), 171-189.

Yener, M. ve Aykol S.E.(2009), “Girişimcilik Değerleri ve Örgütsel Vatandaşlık Davranışı Üzerine Bir Araştırma”, Süleyman Demirel Üniversitesi İktisadi ve İdari Bilimler Fakültesi Dergisi, 14(1), 255271.

Yıldırım F.(2007), “ İş Doyumu İle Örgütsel Adalet İlişkisi ”, Ankara Üniversitesİ SBF Dergisi 62(1), 253 278 